\title{
Arbuscular mycorrhizal fungi and alien plant species
}

\section{Opinion}

It is debated that alien plants in environments benefit from being arbuscular mycorrhizal fungi (AM fungi) and whether widely distributed natives and aliens differ in their associations with AM fungi. Biological invasion is one of the major threats associated with global change due to its impact on biodiversity and ecosystem. The direction and degree to which invasive alien and native plants are influenced by mycorrhizal associations could indicate a general mechanism of plant invasion, but whether or not such differences exist is unclear. The introduction of alien plants can influence biodiversity and ecosystems. However, its consequences for soil microbial communities remain poorly understood. The negative consequences of plant invasions have stimulated extensive research to identifying the responsible mechanisms and identify efficacious management strategies. Numbers of alien plant species have been increasing in floras around the world, ${ }^{1}$ and interest in the processes and mechanisms underlying the successful establishment and spread of aliens in new environments has emerged in parallel..$^{2,3}$

The invasion success of alien plant species depends, amongst other things, on their functional traits ${ }^{4}$ and the susceptibility of ecosystems. There is now increasing interest in including biotic interactions particularly mutualistic associations, ${ }^{5}$ into frameworks assessing alien plant invasions, as they help bridge the invisibility and invasiveness features. The great majority of terrestrial plant species are associated with AM fungi, ${ }^{6}$ and these appear to be important in determined the ecology of plant species and communities. ${ }^{78}$ The function of the AM fungal symbiosis during the alien plant invasion process has subsequently gained increasing consideration. AM fungi can increase growth and competitiveness of spotted knapweed (Centaurea stoebe) which is one of the most invasive weeds in the intermountain west of the USA. ${ }^{9}$ Euphorbia esula increases AM fungi abundance and diversity compared to remnant native communities. ${ }^{10}$ According to ${ }^{11}$ insignificant difference between invasive and native plants in their growth responses to AM fungi, signifying that invasions do not select for directional shifts in AM fungi associations.

According to ${ }^{12}$ the storage organs and retention of the AM fungi symbiosis may characterize to compete carbon (C) sinks. The AM fungal symbiosis potentially affects nutrient uptake and the $\mathrm{C}$ economy of plant species. AM fungi can supply up to $90 \%$ of plant phosphorus (P) uptake, up to $20 \%$ of nitrogen $(\mathrm{N})$ uptake, and consume a significant fraction of plant net primary production. ${ }^{1}$ Hence, despite the benefits plants gain from the symbiosis, there is a potential cost in terms of $\mathrm{C}$ provided to the fungal partner, and trade-offs between retention of the mycorrhizal symbiosis and the development of other C-costly plant properties have been predicted. ${ }^{13}$ It can be concluded that alien plant species and their relationship with the AM fungi were related to trades of $\mathrm{C}$ allocation, and that these differences affect the distribution of those species groups. Incorporating plant mycorrhizal status and other mycorrhiza-related plant functional traits may thus help to provide further understanding of the establishment of alien plant species and their invasion success. ${ }^{14-16}$

\section{Acknowledgements}

None.
Volume 2 Issue I - 2018

\author{
Pradeep Kumar Singh \\ Department of Botany, Goswami Ganesh Datta Sanatan Dharma \\ College, India
}

Correspondence: Pradeep Kumar Singh, Department of Botany, Goswami Ganesh Datta Sanatan Dharma College, India, Tel 7347666567,Email pradeep.kumar@ggdsd.ac.in

Received: January 09, 2018 | Published: January 16, 2018

\section{Conflict of interest}

The authors declare that there is no conflict of interest.

\section{References}

1. van Kleunen M, Dawson W, Essl F, et al. Global exchange and accumulation of non-native plants. Nature. 2015;525(7567):100-103.

2. Blackburn TM, Pysek P, Bacher S, et al. A proposed unified framework for biological invasions. Trends Ecol Evol. 2011;26(7):333-339.

3. Richardson DM, Pysek P. Naturalization of introduced plants: ecological drivers of biogeographical patterns. New Phytol. 2012;196(2):383-396.

4. Kuster EC, Kuhn I, Bruehlheide H, et al. Trait interactions help explain plant invasion success in the German flora. $J$ Ecol. 2008;96:860-868.

5. Traveset A, Richardson DM. Mutualistic interactions and biological invasions. Ann. Rev Ecol Evol S. 2014;45:89-113.

6. Smith SE, Read D. Mycorrhizal Symbiosis. 3rd ed. Elsevier, Netherlands; 2008.

7. Singh PK, Mishra M, Vyas D. Interactions of vesicular arbuscular mycorrhizal fungi with Fusarium wilt and growth of the tomato. Indian Phytopathology. 2010;63(1):30-34.

8. Klironomos J, Zobel M, Tibbett M, et al. Forces that structure plant communities: quantifying the importance of the mycorrhizal symbiosis. New Phytol. 2011;189(2):366-370.

9. Marlers MJ, Zabinski CA, Callaway RM. Mycorrhizae indirectly enhance competitive effects of an invasive forb on a native bunchgrass. Ecology. 1999;80(4):1180-1186.

10. Lekberg Y, Gibbons SM, Rosendahl S, et al. Severe plant invasions can increase mycorrhizal fungal abundance and diversity. ISME J. 2013;7(7):1424-33.

11. Bunn RA, Ramsey PW, Lekberg Y. Do native and invasive plants differ in their interactions with arbuscular mycorrhizal fungi? A meta-analysis. J Ecol. 2015;103(6):1547-1556.

12. Grman E. Plant species differ in their ability to reduce allocation to nonbeneficial arbuscular mycorrhizal fungi. Ecology. 2012;93:711-718.

13. Reinhart KO, Wilson GWT, Rinella MJ. Predicting plant responses to mycorrhizae: integrating evolutionary history and plant traits. Ecol Lett. 2012;15(7):689-695.

14. Mitchell CE, Agrawal AA, Bever JD, et al. Biotic interactions and plant invasions. Ecol Lett 2006;9(6):726-740. 
15. Pysek P, Jarosik V, Pergl J, et al.The global invasion success of Central European plants is related to distribution characteristics in their native range and species traits. Divers Distrib. 2009;15:891-903.
16. van der Heijden MGA, Martin FM, Selosse MA, et al. Mycorrhizal ecology and evolution: the past, the present, and the future. New Phytol.2015;205(4):1406-1423. 